\title{
Pengaruh Pijat Bayi Terhadap Kenaikan Berat Badan Bayi di Klinik Zada Care
}

\author{
Penulis: \\ Desi Ernita Amru ${ }^{1}$ \\ Sri Dewi Haryati ${ }^{2}$ \\ Hazen Aziz
}

Afiliasi :

Institut Kesehatan Mitra Bunda ${ }^{1,2,3}$

\section{Korespondensi:}

dhesyamru@yahoo.co.id

Histori Naskah:

Diajukan: 2022-01-22

Disetujui: 2022-01-22

Publikasi: 2022-01-22

\begin{abstract}
Abstrak:
Banyak upaya yang dilakukan orang tua untuk mengoptimalkan kenaikan berat badan bayinya. Kenaikan berat badan pada bayi sangat peka terhadap lingkungan dan membutuhkan asupan gizi serta stimulasi yang baik. Salah satu metode yang dianggap efektif yaitu dengan prosedur dan teknik pijat bayi. Tujuan penelitian ini adalah untuk mengetahui Pengaruh Pijat Bayi Terhadap Kenaikan Berat Badan Bayi di Zada Care. Metode penelitain yang digunakan adalah Pre Experimental Designs dengan rancangan one grup pretest-posttest. Dimana dilakukan pengukuran sebelum dan setelah tindakan (pijat bayi) Untuk mengetahui perbedaan sebelum dan sesudah dilakukan tindakan pijat bayi. Hasil menunjukkan rata-rata berat badan pertama (pre-test) 5180,88 dan kedua (post-test) 5535,29. Hasil uji $\mathrm{T}$ diperoleh $\mathrm{p}=0,000<0,05$, artinya ada pengaruh pijat bayi terhadap kenaikan berat badan bayi. Berdasarkan uji statistic ada pengaruh pijat bayi sebelum dan setelah dilakukan pemijatan terhadap peningkatan berat badan bayi di Klinik Zada Care Kota Batam.
\end{abstract}

Kata kunci: Bayi, Berat badan, Pijat bayi

\section{Pendahuluan}

Masa tumbuh kembang bayi merupakan masa keemasan sekaligus masa kritis perkembangan seseorang yaitu pada usia 0-12 bulan. Dikatakan masa keemasan karena masa bayi berlangsung sangat singkat dan tidak dapat diulang kembali. Dikatakan masa kritis karena pada masa ini bayi sangat peka terhadap lingkungan dan membutuhkan asupan gizi serta stimulasi yang baik untuk pertumbuhan dan perkembanganya (Marmi K, R 2015).

Tumbuh kembang pada bayi tidak terlepas dari konsep pertumbuhan dan perkembangan. Pertumbuhan adalah perubahan fisik dan peningkatan ukuran bagian tubuh dari seorang individu yang masing-masing berbeda, sedangkan perkembangan adalah bertambah sempurnanya kemampuan, keterampilan, dan fungsi tubuh yang lebih kompleks dalam kemampuan motorik kasar, motorik halus, bicara dan bahasa, serta sosialisasi dan kemandirian yang dimiliki individu untuk beradaptasi dengan lingkungan (D 2013).

Menurut World Healthy Organitation (WHO) secara global sekitar 20-40\% bayi usia 0-2 tahun mengalami masalah keterlambatan dalam proses perkembangan. Prevalensi masalah perkembangan anak diberbagai negara maju dan berkembang di antaranya Amerika sebesar 12-16\%, Argentina 22\% dan Hongkong 23\%. Beberapa penelitian yang telah di evaluasi berdampak kegagalan bahkan memperpendek usia hidup (Kementerian Kesehatan RI Badan Penelitian dan Pengembangan 2018)

Menurut Depkes RI (2019) menyatakan bahwa 16\% bayi di Indonesia mengalami gangguan perkembangan saraf dan otak mulai ringan sampai berat. Pada masa bayi dan balita, perkembangan 
kemampuan berbahasa, kreativitas, kesadaran sosial, emosional dan intelejensi berjalan sangat cepat dan merupakan landasan perkembangan berikutnya. Kurangnya rangsangan yang diberikan pada bayi menambah keterlambatan pada bayi. Banyak riset menunjukkan bayi membutuhkan rangsangan dini diberbagai bagian tubuh dan alat-alat indera untuk membantu bayi dalam penyesuaian diri terhadap lingkungan barunya (Kemenkes RI 2019).

Ikatan Dokter Anak Indonesia kepulauan Riau (2018) melakukan pemeriksaan terhadap 2.634 anak dari usia 0-72 bulan. Dari hasil pemeriksaan untuk perkembangan ditemukan normal sesuai dengan usia sebanyak 53\%, meragukan (membutuhkan pemeriksaan lebih dalam) sebanyak 13\%, penyimpangan perkembangan sebanyak 34\%. Berdasarkan data di atas terlihat bahwa angka meragukan dan penyimpangan perkembangan masih cukup besar di Indonesia (Dinas Kesehatan Kota Batam 2018).

Data Dari Dinas Kesehatan Kota Batam (tahun 2018) angka kelahiran hidup berjumlah 312.707 bayi, melihat tingginya angka kelahiran hidup pada bayi penting sekali memberi stimulus pada masa golden age sehingga tidak terjadi keterlambatan perkembangan. Status tumbuh kembang bayi dan balita di kota Batam sebanyak 15,1\% bayi mengalami gizi kurang yang kemudian menyebabkan keterlambatan dalam proses perkembangan. Stimulasi atau rangsangan yang baik untuk anak dapat diberikan oleh orang tua untuk perkembangan potensinya secara maksimal (Dinas Kesehatan Kota Batam 2016).

Faktor yang berhubungan dengan tumbuh kembang anak yaitu nutrisi yang tercukupi, lingkungan keluarga yang mendukung merupakan dasar untuk tumbuh kembang anak. Selain itu dari segi personal anak dapat diberikan stimulasi, salah satu bentuk stimulasi yang umum dilakukan orang tua untuk bayi adalah stimulasi taktil dalam bentuk pijat bayi (Rusmil 2016).

Pemerintah dalam hal ini telah memberikan perhatian terhadap bayi melalui peran Bidan sendiri yang tertuang dalam Keputusan Menteri Kesehatan Republik Indonesia Nomor 28 Tahun 2017 tentang Standar Profesi Bidan menyebutkan bahwa bidan mempunyai kewenangan untuk melaksanakan pemantauan dan menstimulasi tumbuh kembang bayi dan anak. Salah satu bentuk stimulasi tumbuh kembang yang selama ini dilakukan yaitu pijat bayi (Sundoyo 2017).

Pijat merupakan salah satu metode pengobatan tertua di dunia. Pijat meliputi seni perawatan kesehatan dan pengobatan yang mampu melemaskan sendi yang terlalu kaku dan menyatukan organ tubuh dengan gosokan yang kuat. Terapi pijat tidak hanya digunakan di salon dan spa saja, tetapi juga di berbagai rumah sakit dan pusat perawatan kesehatan. Saat ini teknik pijat telah banyak digunakan untuk kesehatan dan peningkatan berat badan pada bayi (Aswitami and Udayani 2019).

Dari penelitian yang dilakukan di sebuah Rumah Sakit Swasta di Bandung, yang dilakukan terhadap bayi cukup bulan, secara acak dibagi dalam 2 kelompok yaitu kelompok pemijatan dan kelompok kontrol. Pemijatan dimulai sejak bayi usia 4 minggu yang dilakukan oleh ibunya setiap hari 1-2 kali perhari. Ternyata didapatkanhasil yang memperlihatkan perbedaan pertumbuhan berat badan yang sangat bermakna (Rosalina, 2007).

Pada penelitian yang dilakukan oleh andini, dkk pada tahun 2014 tentang pengaruh pijat bayi terhadap perkembangan neonatus menunjukkan terdapat peningkatan perkembangan motorik yang signifikan setelah dilakukan pijat bayi. Hal tersebut dapat disimpulkan bahwa pemberian pijat bayi dapat mengoptimalkan perkembangan neonatus. Berdasarkan survey data awal hasil penimbangan berat badan bayi di wilayah kerja Puskesmas Pematang Pasir Kota Tanjung Balai, terdapat 120 bayi yang tercatat melakukan penimbangan di posyandu dan hasilnya hanya terdapat 65 bayi atau sekitar $54 \%$ yang mengalami kenaikan berat badan, sisanya 55 bayi atau sekitar $46 \%$ bayi tidak mengalami kenaikan berat badan yang seharusnya. Rata-rata ibu bayi tersebut tidak mengetahui dan tidak pernah melakukan cara perawatan kesehatan bayi dengan stimulasi pertumbuhan bayi dengan menggunakan 
pijat bayi. Observasi awal yang dilakukan oleh penulis pada petugas kesehatan di wilayah kerja Puskesmas Pematang Pasir bahwa belum ada yang melakukan teknik pemijatan bayi secara spesifik yang berguna untuk meningkatkan kesehatan dan perawatan bayi

Berdasarkan latar belakang diatas peneliti tertarik untuk melakukan penelitian dengan judul "Pengaruh Pijat Bayi Terhadap Kenikan Berat Badan Bayi di Zada Care Kota Batam".

\section{Studi Literatur}

1. Pengertian

Bayi adalah masa tahapan pertama kehidupan seorang manusia setelah lahir dari rahim seorang ibu. Pada masa ini, perkembangan otak dan fisik bayi selalu menjadi perhatian utama (Putra 2017).

Masa bayi adalah masa keemasan sekaligus masa kritis perkembangan seseorang. Masa bayi dibagi menjadi dua periode, yaitu masa neonatal dan masa post neonatal. Masa neonatal dimulai dari umur 0 sampai 28 hari, sedangkan masa post neonatal dimulai dari umur 29 hari sampai 11 bulan (Dewi 2016).

2. Pertumbuhan dan Perkembangan Anak

Meskipun pertumbuhan dan perkembangan mempunyai arti yang berbeda, namun keduanya saling mempengaruhi dan berjalan secara stimulant (bersamaan). Pertambahan ukuran fisik akan disertai dengan pertambahan kemampuan (pekembangan anak) (Soetjiningsih 2018).

\section{Defenisi Pijat Bayi}

Pijat Bayi adalah seni perawatan kesehatan dan pengobatan yang di kenal sejak awal manusia di ciptakan di dunia serta telah di praktekkan sejak berabad-abad silam secara turun temurun oleh dukun bayi. (Roesli, 2001). Pijat bayi (stimulus touch) adalah terapi sentuhan kulit dengan menggunakan tangan. Pijat Bayi adalah terapi sentuhan tertua dan terpopuler yang di kenal manusia, yang juga merupakan seni perawatan kesehatan dan pengobatan yang dipraktikkan sejak berabad-abad silam (Khuzaiyah 2018).

\section{Metode Penelitian}

Jenis Jenis penelitian yang digunakan pada penelitian ini adalah Pre Experimental Designs dengan rancangan one grup pretest-posttest. Dimana dilakukan pengukuran sebelum melakukan perlakuan (pretest) (Sugiono 2017) kemudian dilakukan perlakuan yaitu tindakan pijat bayi lalu setelah diberikan perlakukan dilakukan pengukuran kembali (posttest). Untuk mengetahui perbedaan sebelum dan sesudah dilakukan tindakan pijat bayi. Populasi dalam penelitian ini adalah bayi usia 0-1 tahun yang datang ke Klinik Zada Care berjumlah 32 bayi.

\section{Hasil}

\section{Analisis Univariat}

Analisa Univariat untuk mengetahui gambaran subjek penelitian dan variabel - variabel penelitian

Tabel 1

Distribusi Frekuensi Responden Berdasarkan Usia 0-1 Tahun

Di Klinik Zada Care Kota Batam 
Volume: 1 | Nomor 1 | Januari 2022 |E-ISSN: 2809-911X |

DOI: doi.org/healthcaring.v1n1.1342

\begin{tabular}{ccc}
\hline Pertumbuhan & Frekuensi & Frekuensi (\%) \\
\hline 1 Bulan & 12 & 37,5 \\
2 Bulan & 9 & 28,1 \\
3 Bulan & 11 & 34,4 \\
\hline Jumlah & 32 & $100 \%$
\end{tabular}

Berdasarkan tabel 1 didapatkan responden terbanyak berusia 1 bulan berjumlah 12 orang $(937,5 \%)$ dan yang paling sedikit berusia 2 bulan sebanyak 9 orang $(28,1 \%)$.

Tabel 2

Distribusi Frekuensi Responden Berdasarkan Jenis Kelamin

Di Klinik Zada Care Kota Batam

\begin{tabular}{lcc}
\hline \multicolumn{1}{c}{ Jenis Kelamin } & Frekuensi & Presentase (\%) \\
\hline Laki-Laki & 19 & $59,4 \%$ \\
Perempuan & 13 & $40,6 \%$ \\
\hline Jumlah & 32 & $100 \%$ \\
\hline
\end{tabular}

Berdasarkan tabel diatas, dapat dilihat dari 32 respondenjenis kelamin laki-laki lebih banyak dari pada perempuan, dengan jumlah 19 orang $(59,5 \%)$.

Tabel 3

Distribusi Berat Badan Bayi Berdasarkan Usia

Di Klinik Zada Care Kota Batam

\begin{tabular}{ccc}
\hline Usia & Berat Badan Bayi (Gram) & Mean (Gram) \\
\hline 1 Bulan & 30100 & 3957 \\
2 Bulan & 43110 & 5273 \\
3 Bulan & 63890 & 6673
\end{tabular}

Berdasarkan tabel 3 rata-rata berat badan bayi lebih besar pada usia 3 bulan dan lebih kecil pada usia 1 bulan.

\section{Analisis Bivariat}

Tabel 4

Distribusi Frekuensi Responden Berdasarkan Peningkatan

Berat Badan Di Klinik Zada Care Kota Batam

\begin{tabular}{ccc}
\hline Peningkatan Berat Badan & Frekuensi & Persentasi (\%) \\
\hline Meningkat & 27 & 84,4
\end{tabular}

This is an Creative Commons License This work is licensed under a Creative Commons AttributionNonCommercial 4.0 International License 


\begin{tabular}{ccc} 
Menurun & 1 & 3,1 \\
Tetap & 4 & 12,5 \\
\hline Jumlah (n) & 32 & 100 \\
\hline $\begin{array}{l}\text { Berdasarkan Tabel diatas, responden yang mengalami peningkatan berat badan } \\
\text { sebanyak } 27 \text { orang }(84,4 \%), \text { responden yang tidak mengalami peningkatan berat badan } \\
\text { sebanyak } 4 \text { orang }(12,5 \%) \text { dan sisanya yang tidak mengalami peningkatan ataupun } \\
\text { penurunan berat badan sebanyak 1 orang }(3,1 \%) .\end{array}$
\end{tabular}

Tabel 5

Pengaruh Pijat Bayi Terhadap Kenaikan Berat Badan Sebelum dan Sesudah Pemijatan Di Klinik Zada Care Kota Batam

\begin{tabular}{lccc}
\hline \multicolumn{1}{c}{ Variabel } & t-hitung & Sig. & Level of Significant \\
\hline Pre-test dan Post-test & 11,533 & 0,000 & 0,05 \\
\hline $\mathrm{n}=32$ & & &
\end{tabular}

Berdasarkan tabel Paired Sample t-test diperoleh signifikansi 0,000 kurang dari taraf signifikan $(\alpha)=0,05$, maka H0 ditolak. Artinya ada perbedaan yang signifikan antara sebelum dan sesudah dilakukan Pijat Bayi.

\section{Pembahasan}

Berdasarkan tabel 5 diperoleh signifikansi 0,000 kurang dari taraf signifikan $(\alpha)=0,05$, maka H0 ditolak. Artinya ada perbedaan yang signifikan antara sebelum dan sesudah dilakukan Pijat Bayi.

Peningkatan berat badan pada bayi sangat dipengaruhi oleh pijat bayi yang diberikan secara kontiniu. Pada dasarnya bayi yang dipijat akan mengalami peningkatan kadar enzim penyerapan dan insulin sehingga penyerapan terhadap sari makanan pun menjadi lebih baik. Hasilnya, bayi menjadi cepat lapar dan karena itu lebih sering menyusu sehingga meningkatkan produksi ASI (Siti Husaidah, Desi Ernita Amru 2020). Pemijatan juga meningkatkan mekanisme penyerapan makanan oleh nervus vagus sehingga nafsu makan bayi juga akan meningkat yang dapat secara langsung meningkatkan berat badan bayi.

Menurut Rini Sekartin, dokter spesialis anak dari Fakultas Kedokteran Universitas Indonesia, pijatan pada bayi mampu merangsang motorik, membantu proses tidur, mengurangi rasa cemas dan keluhan. Terjadi peningkatan zat-zat makanan di saluran pencernaan dan mengembangkan mental anak, membuat suhu tubuh bisa lebih stabil serta mampu meningkatkan hormon gastrin dan insulin yang berperan dalam penyerapan makanan sehingga berat badan bayi naik lebih cepat (Waladow, Warouw, and Rottie 2018).

Berdasarkan pengamatan secara kualitatif, diketahui bahwa faktor-faktor perancu seperti asupan nutrisi yang didapatkan oleh responden penelitian ini juga memberi pengaruh yang cukup bermakna. Penelitian pijat bayi juga dilakukan oleh Universitas Gajah Mada pada tahun 2012, pijat bayi merupakan peluang yang berpengaruh terhadap peningkatan berat badan sebesar 2,68\%. Kenaikan 
berat bayi berat lahir rendah yang diberikan perlakuan pijat selama 10 hari lebih besar dibandingkan dengan bayi yang tidak dilakukan pijat (Asmar Yetti 2017).

Penelitian lain yang telah dilakukan oleh Underdown, (2006) seorang peneliti masalah anak dari Warwick Medical School, Institute of Education dan Universiity Warwick Coventry menyatakan bahwa pemijatan yang dilakukan pada bayi dan balita akan meningkatkan kesehatan fisik dan ketahanan tubuh dari berbagai penyakit. Pijat bayi juga diteliti oleh Stikes Fort De Kock Bukit tinggi, rata-rata berat badan pada minggu pertama sebesar 5.716,67 gram dari ke 12 responden bayi usia 3-4 bulan kemudian dilakukan pijat bayi selama kurang lebih 15 menit sebanyak empat kali setiap minggu dalam waktu 1 bulan. Rata-rata berat badan bayi meningkat menjadi 6.366,67. Dari uraian tersebut dapat diketahui bahwa terjadi peningkatan sebesar 650 gram (Movements 2019).

Penelitian ini juga, didukung dengan penelitian T.Field dan Scafidi (1986 dan 1990, dalam Roesli, 2008, hal 12) yang menunjukkan bahwa pada 20 bayi premature (berat badan 1.280 dan $1.176 \mathrm{gr}$ ), yang dipijat selama 3 kali 15 menit selama 10 hari, terjadi kenaikan berat badan 20\% - 47\% per hari, lebih dari yang tidak dipijat. Seperti yang sudah dijelaskan bahwa terdapat beberapa faktor yang dapat mempengaruhi penigkatan berat badan pada bayi diantaranya adalah pengetahuan ibu mengenai gizi, status kesehatan, psikologi bayi, serta faktor pribadi dan kesukaan belum dapat disingkirkan sebagai faktor perancu penelitian ini (G Primanta 2016).

Bayi yang dipijat mengalami peningkatan kadar enzim penyerapan dan insulin sehingga penyerapan terhadap sari makanan pun menjadi lebih baik. Hasilnya, bayi menjadi cepat lapar dan karena itu lebih sering menyusu sehingga meningkatkan produksi ASI (Suparyanto 2011). Pemijatan juga meningkatkan mekanisme penyerapan makanan oleh nervus vagus sehingga nafsu makan bayi juga akan meningkat yang dapat secara langsung meningkatkan berat badan bayi (Putri and Sukandar 2017).

Status sosial ekonomi dan budaya pangan mempunyai tanggung jawab yang cukup besar terhadap status kesehatan bayi. Namun, secara khusus penelitian ini membuktikan bahwa pemberian pijat bayi dapat membantu mengoptimalkan pertumbuhan bayi dengan peningkatan berat badan bayi. Bayi yang dipijat mengalami peningkatan kadar enzim penyerapan dan insulin sehingga penyerapan terhadap sari makanan pun menjadi lebih baik. Hasilnya, bayi menjadi cepat lapar dan karena itu lebih sering menyusu sehingga meningkatkan produksi ASI (Herlina 2018).

Pemijatan juga meningkatkan mekanisme penyerapan makanan oleh nervus vagus sehingga nafsu makan bayi juga akan meningkat yang dapat secara langsung meningkatkan berat badan bayi (Syaukani, 2015). Aktifitas pemijatan akan meningkakan aktifitas neorotransmitter serotin, yaitu meningkatkan kapasitas sel reseptor yang berfungsi meningkatkan glucocorticoid (adrenalin, suatu hormon stres). Proses ini akan menyebabkan terjadinya penurunan kadar hormon adrenalin (hormon stres) penurunan kadar hormon stres ini akan meningkatkan daya tahan tubuh, terutama $\operatorname{IgM}$ dan $\operatorname{IgG}$. Pijat bayi akan membuat bayi tidur lebih lelap dan meningkatkan kesiagaan (alertness) atau konsentrasi. Hal ini dikarenakan pijatan yang baik dapat mengubah gelombang otak. Pengubahan ini terjadi dengan cara menurunkan gelombang alpha dan meningkatkan gelombang beta serta tetha yang dapat dibuktikan dengan penggunaan EEG (electro encephalogram) (Syaukani, 2015).

Berdasarkan hasil penelitian pengaruh pijat bayi terhadap peningkatan berat badan bayi yang telah saya lakukan, telah diketahui bahwa pijat bayi memberikan manfaat yang sangat besar terhadap pertumbuhan bayi terutama peningkatan berat badan bayi. Selain itu, pijat bayi juga telah dibuktikan efektifitasnya terhadap pertumbuhan dan perkembangan bayi oleh beberapa peneliti dari berbagai universitas dan dan para ahli menyatakan bahwa bayi yang rutin diberikan pijat bayi akan memiliki sistem imunitas yang lebih tinggi (bayi tidak gampang sakit) dan menunjukan sikap perkembangan 
motorik yang lebih cepat dibandingkan dengan bayi yang tidak diberikan pijat bayi. Oleh karena itu, perlu adanya penerapan stimulasi bayi menggunakan pijat bayi agar pertumbuhan dan perkembangan bayi lebih optimal guna meningkatkan kualitas sumber daya manusuia yang unggul yang tercipta dan terasah pada 1000 hari pertama kehidupannya.

\section{Kesimpulan}

1. Ada peningkatan berat badan bayi setelah dilakukan pemijatan di Klinik Zada Care Kota Batam.

2. Dari hasil penelitian yang dilakukan berat badan bayi yang meningkat adalah sebanyak 27 bayi dari 32 bayi yang menjadi responden di Klinik Zada Care Kota Batam.

3. Berdasarkan uji statistic ada pengaruh pijat bayi sebelum dan setelah dilakukan pemijatan terhadap peningkatan berat badan bayi di Klinik Zada Care Kota Batam.

\section{Referensi}

Asmar Yetti. 2017. "Pengaruh Pijat Bayi Dengan Berat Badan Lahir Rendah Terhadap Kenaikan Berat Badan Bayi Di RSUD Bantul."

Aswitami, Gusti Ayu Pramita, and dkk Udayani. 2019. "Pengaruh Pijat Bayi Terhadap Durasi Tidur Pada Bayi Umur 1-3 Bulan." Care: Jurnal Ilmiah Ilmu Kesehatan 7(2):1. doi: 10.33366/jc.v7i2.1035.

D, Adriana. 2013. Tumbuh Kembang \& Terapi Bermain Pada Anak. Jakarta: Selemba Medika.

Dewi, Vivian Nanny Lia. 2016. Asuhan Neonatus Bayi Dan Anak Balita. Jakarta: Salemba Medika.

Dinas Kesehatan Kota Batam. 2016. Dinas Kesehatan. Batam.

Dinas Kesehatan Kota Batam. 2018. "Profil Kesehatan Kota Batam Tahun 2018." Profil Kesehatan Kota Batam (54):38-74.

G Primanta, Anggun. 2016. "Pengaruh Pijat Bayi Terhadap Perubahan Berat Badan Bayi Skripsi Anggun Primanta." Analisis Standar Pelayanan Minimal Pada Instalasi Rawat Jalan Di RSUD Kota Semarang 103-11.

Herlina, Sara. 2018. "Tumbuh Kembang Bayi Yang Mendapatkan Asi Eksklusif Diwilayah Kerja Puskesmas Simpang Baru Kota Pekanbaru." Jurnal Kebidanan 7(2):166. doi: 10.26714/jk.7.2.2018.166-176.

Kemenkes RI. 2019. Profil Kesehatan Indonesia 2018 [Indonesia Health Profile 2018].

Kementerian Kesehatan RI Badan Penelitian dan Pengembangan. 2018. "Hasil Utama Riset Kesehatan Dasar.” Kementrian Kesehatan Republik Indonesia. doi: 1 Desember 2013.

Khuzaiyah, Siti. 2018. "Peningkatan Keterampilan Ibu Dalam Melakukan Pijat Bayi Melalui Kelas Pijat Bayi Oleh Certified Infant Massage Insstructure ( CIMI )." The 7th University Research Colloqium 2018 STIKES PKU Muhammadiyah Surakarta (Cimi):586-91.

Marmi K, R, . 2015. Asuhan Neonatus, Bayi, Balita, Dan Anak Prasekolah. Yogyakarta: Pustaka Pelajar.

Movements, Smooth Bowel. 2019. "Efektifitas Pijat Bayi Terhadap Peningkatan Berat Badan, Lama Waktu Tidur Dan Kelancaran Buang Air Besar.” 12(2):9-16. 
Volume: 1 | Nomor 1 | Januari 2022 | E-ISSN: 2809-911X |

DOI: doi.org/healthcaring.v1n1.1342

Putra, Sitiatava Rizema. 2017. Asuhan Neonatus Bayi Dan Balita Untuk Keperawatan Dan Kebidanan. Yogyakarta: D-Medika.

Putri, Desti Sagita, and Dadang Sukandar. 2017. "Keadaan Rumah, Kebiasaan Makan, Status Gizi, Dan Status Kesehatan Balita Di Kecamatan Tamansari, Kabupaten Bogor." Jurnal Gizi Dan Pangan 7(3):163. doi: 10.25182/jgp.2012.7.3.163-168.

Rusmil, Kusnandi. 2016. Pedoman Pelaksanaan Stimulasi, Deteksi Dan Intervensi Dini Tumbuh Kembang Anak. Jakarta: Depkes RI.

Siti Husaidah, Desi Ernita Amru, Sumarni. 2020. "Hubungan Antara Tingkat Pendidikan Dan Pengetahuan Ibu Nifas Dengan Pemberian Asi Eksklusif Di Puskesmas Batua Makassar 2019." Jurnal Sehat Mandiri 15(1):130-39.

Soetjiningsih. 2018. Tumbuh Kembang Anak Edisi 2. Jakarta: EGC.

Sugiono. 2017. Metodologi Penelitian. Bandung: Alfabeta.

Sundoyo. 2017. "Permenkes RI No 28 Tahun 2017 Tentang Penyelenggaraan Praktik Bidan.” 6:5-9.

Waladow, G., S. Warouw, and J. Rottie. 2018. "Hubungan Pola Makan Dengan Status Gizi Pada Anak Usia 3-5 Tahun Di Wilayah Kerja Puskesmas Tompaso Kecamatan Tompaso." Jurnal Keperawatan UNSRAT 1(1):105788. 